\title{
Influence of some Trace Elements and Biochemical Parameters on Breast Cancer
}

\author{
Ameera Aziz Mahmood \\ Kinda Masood Bilal \\ Rana Talib Ibrahim \\ Department of Chemistry / College of Education \\ University of Mosul
}

Received
$04 / 11 / 2010$
Accepted

06 / 04 / 2011

\section{الخلاصة}

تهتم الدراسة بتقدير مستوى المعادن ال نادرة، إضافة الى مستوى البروتين الكلي

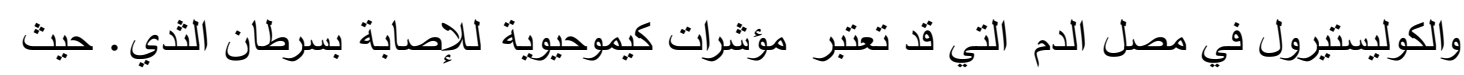

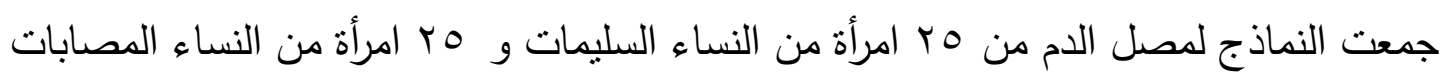

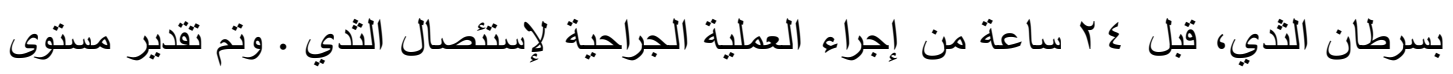

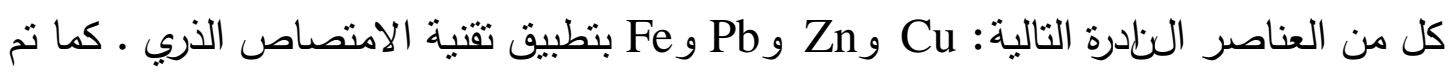

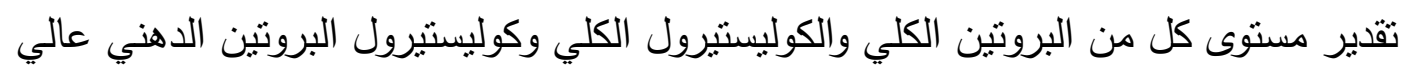

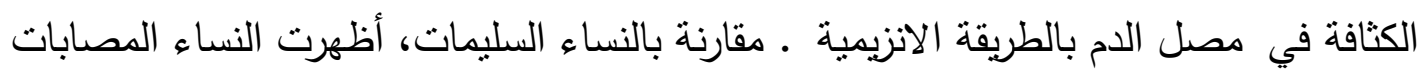

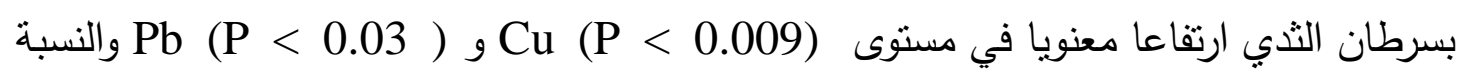

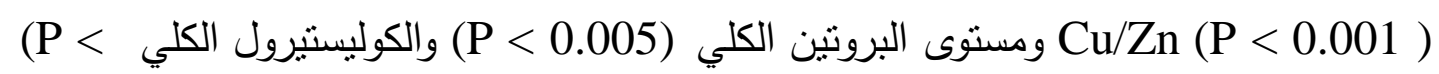

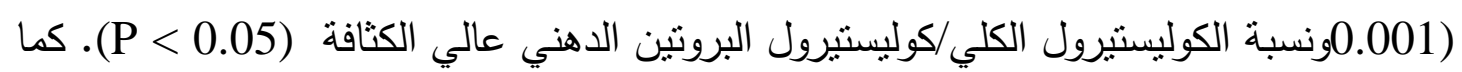

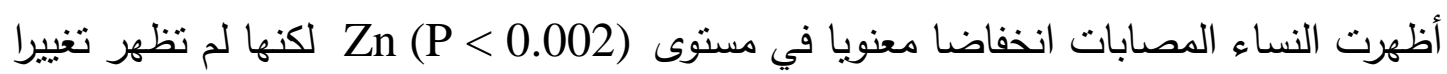

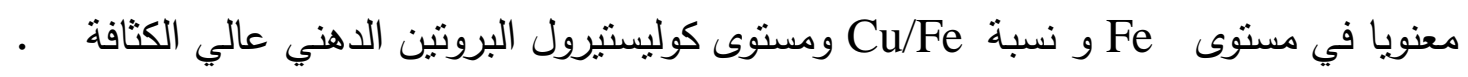

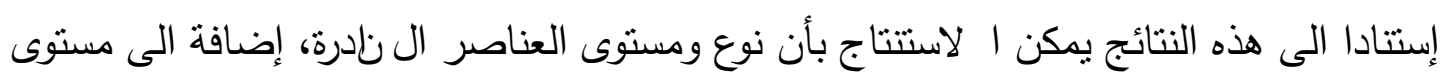

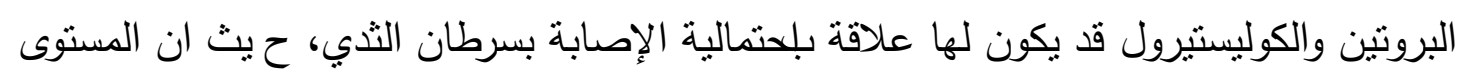

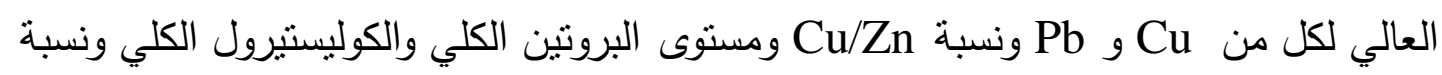

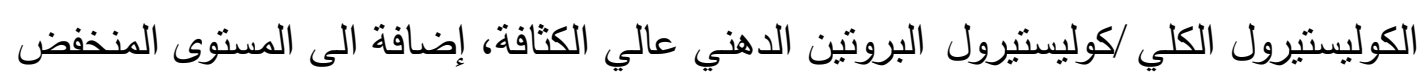

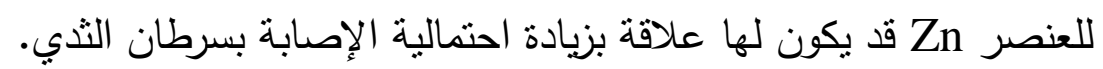

\section{Abstract}


The study investigates the levels of serum trace elements as well as total protein and cholesterol which may be regarded as biochemical markers in the case of breast cancer. Serum samples were collected from 25 healthy females and 25 females with breast cancer, 24 hours before mastectomy surgery. Serum $\mathrm{Cu}, \mathrm{Zn}, \mathrm{Pb}$ and Fe were measured by using the atomic absorption spectrophotometer. Total protein, total cholesterol and HDL-cholesterol were analyzed enzymatically. Compared with the healthy females, the females with breast cancer exhibited a significant increase in the level of $\mathrm{Cu}(\mathrm{p}<0.009), \mathrm{Pb}(\mathrm{p}<0.03), \mathrm{Cu} / \mathrm{Zn}$ ratio $(\mathrm{p}<0.001)$, total protein $(\mathrm{p}<0.005)$, total cholesterol $(\mathrm{p}<0.001)$ and total cholesterol/HDL-cholesterol ratio $(\mathrm{p}<0.05)$. They also exhibited a significant decrease in the level of $\mathrm{Zn}(\mathrm{p}<0.002)$, but there was no significant change in the level of $\mathrm{Fe}, \mathrm{Cu} / \mathrm{Fe}$ ratio and HDL-cholesterol. It was concluded that the type and level of the elements and the level of protein and cholesterol might have a correlation with breast cancer; a high level of $\mathrm{Cu}, \mathrm{Pb}, \mathrm{Cu} / \mathrm{Zn}$ ratio, total protein, total cholesterol and total cholesterol/HDL-cholesterol ratio, and a low level of $\mathrm{Zn}$ may be associated with an increased risk of breast cancer.

\section{Introduction}

At least one-third of all human cancer may be associated with diet and influenced by lifestyle and physical exercise [1].

One of the most common malignancies in women is breast cancer which is considered to be the leading cancer-related cause of death among women in most developed countries [2].

Unfortunately, there has been no effective therapy to prevent this disease. Given this, a large number of epidemiological studies have been undertaken to identify the potential risk factor for cancer [3].

Although there has been a growing recognition that metal compounds are an important class of environmental and occupational carcinogens [4], trace elements or heavy metals have received little attention [2,5]. Trace elements are present in minute quantities, but they play a vital role in many biochemical enzymatic reactions and have been examined critically as a potential key factor in various human diseases including cancer [6]. Trace elements may contribute to tissue carcinogenesis due to their role in regulating cell proliferation, differentiation and apoptosis [7]. Trace elements, such as copper, zinc, lead and iron, are found naturally in the environment, and human exposure derives from a variety of sources including air, drinking water and food [5].

On the other hand, numerous studies implicated a role for cholesterol in the mechanism underlying cell proliferation and cancer progression $[8,9,10]$. In addition, there is an inverse change in the level of serumprotein fractions as a result of the acute phase response in which levels of 
several proteins increase or decrease in response to the physiological stresses, such as tissue necrosis and inflammatory conditions [11, 12, 13].

The present study focuses on the correlation between the level of the trace elements noted above, in addition to the level of cholesterol and proteins, of Iraqi females and the probability of causing breast cancer.

\section{Subjects}

\section{Materials and Methods}

The study was conducted on free living subjects and was not strictly controlled for nutrients and energy intake. The subjects included two groups, patient and healthy, of Iraqi females aged 40-60 y. The patient group consisted of 25 females with diagnosed breast cancer (irrespective of its stage), 24 hours before mastectomy surgery, and they were visitors to the surgery clinics of the Al-Zahrawi Teaching Hospital in Mosul province. The healthy (control) group consisted of 25 apparently healthy females which were recruited mostly from members of staff of the hospital. The study excluded patient or controls with any drug therapy.

\section{Blood Sampling and Analysis}

Venous blood samples were drawn at the approval of the hospital management, from the females who showed no objection, into plain tubes, and the serum was separated $2 \mathrm{~h}$ after venipuncture by centrifugation at $3500 \mathrm{rpm}$ for $5 \mathrm{~min}$, then it was stored at $-20^{\circ} \mathrm{C}$ until ready for assay.

The levels of serum trace elements (viz, $\mathrm{Cu}, \mathrm{Zn}, \mathrm{Pb}$ and $\mathrm{Fe}$ ) were determined using the atomic absorption spectrophotometer [14].

The levels of serum total cholesterol (TC), HDL-Cholesterol (HDL-C) and total protein were analyzed enzymatically using commercial reagents (kits obtained from BioMerieux, France).

\section{Statistical Analysis}

The data was subjected to statistical analysis using the student unpaired t-test for comparison of means between patients and controls. All the data were expressed as mean \pm standard deviation of the mean. Pvalues $\leq 0.05$ were considered significant.

\section{Results}

The level of serum trace elements (viz. $\mathrm{Cu}, \mathrm{Zn}, \mathrm{Pb}$ and $\mathrm{Fe}$ ), the $\mathrm{Cu} / \mathrm{Zn}$ ratio and the $\mathrm{Cu} / \mathrm{Fe}$ ratio of healthy females (control group) and females with breast cancer (patient group) are shown in Table1. Compared with the healthy females, the females with breast cancer exhibited a significant increase in the level of $\mathrm{Cu}(\mathrm{P}<0.009), \mathrm{Pb}(\mathrm{P}<0.03)$ and the $\mathrm{Cu} / \mathrm{Zn}$ ratio $(\mathrm{P}<0.001)$. They also exhibited a significant decrease in the level of $\mathrm{Zn}$ 
$(\mathrm{P}<0.002)$, but there was no significant change in the level of $\mathrm{Fe}$ and the $\mathrm{Cu} / \mathrm{Fe}$ ratio.

Table (1): Serum-trace elements levels

\begin{tabular}{|c|c|c|c|}
\hline \multirow{2}{*}{$\begin{array}{c}\text { Serum trace } \\
\text { elements }\end{array}$} & $\begin{array}{c}|c| \\
\text { Healthy women } \\
(\mathrm{n} 25)\end{array}$ & $\begin{array}{c}\text { Breast cancer women } \\
(\mathrm{n} 25)\end{array}$ & \multirow{2}{*}{ P-value } \\
\hline $\mathrm{Cu} \mu \mathrm{g} / 100 \mathrm{ml}$ & $119.344 \pm 19.640$ & $173.928 \pm 32.376 \uparrow$ & 0.0086 \\
\hline $\mathrm{Zn} \mu \mathrm{g} / 100 \mathrm{ml}$ & $115.872 \pm 19.296$ & $81.384 \pm 19.765 \downarrow$ & 0.0019 \\
\hline $\mathrm{Pb} \mu \mathrm{g} / 100 \mathrm{ml}$ & $0.624 \pm 0.347$ & $1.056 \pm 0.586 \uparrow$ & 0.028 \\
\hline $\mathrm{Fe} \mu \mathrm{g} / 100 \mathrm{ml}$ & $165.234 \pm 21.005$ & $177.808 \pm 16.632$ & 0.246 \\
\hline $\mathrm{Cu} / \mathrm{Zn}$ ratio & $1.029 \pm 0.4011$ & $2.129 \pm 0.765 \uparrow$ & 0.0009 \\
\hline $\mathrm{Cu} / \mathrm{Fe}$ ratio & $0.782 \pm 0.378$ & $0.928 \pm 0.401$ & 0.066 \\
\hline
\end{tabular}

* $\mathrm{P} \leq 0.05$ considered significant.

Table 2 shows the levels of the analyzed serum biochemical parameters (viz. TC, HDL-C, total protein and the TC/HDL-C ratio). Compared with the healthy females, the females with breast cancer exhibited a significant increase in the level of total protein and TC $(\mathrm{P}<0.001)$ and the $\mathrm{TC} / \mathrm{HDL}-\mathrm{C}$ ratio $(\mathrm{P}<0.05)$. They also exhibited no significant change in the level of HDL-C.

Table (2): Some Serum Clinical Characteristics

\begin{tabular}{|c|c|c|c|}
\hline \multirow{2}{*}{$\begin{array}{c}\text { Serum Clinical } \\
\text { Characteristics }\end{array}$} & $\begin{array}{c}|c| \\
\text { Healthy women } \\
\text { (n 25) }\end{array}$ & $\begin{array}{c}\text { Breast cancer } \\
\text { women (n 25) }\end{array}$ & * P-value \\
\hline $\begin{array}{c}\text { Total protein } \\
\text { gm/dl }\end{array}$ & $6.655 \pm 0.362$ & $7.791 \pm 1.489$ & 0.004 \\
\hline $\begin{array}{c}\text { Total cholesterol } \\
\text { mmol/L }\end{array}$ & $4.468 \pm 0.480$ & $5.936 \pm 1.098$ & 0.001 \\
\hline $\begin{array}{c}\text { HDL-cholesterol } \\
\text { mmol/L }\end{array}$ & $0.998 \pm 0.222$ & $1.106 \pm 0.292$ & 0.146 \\
\hline $\begin{array}{c}\text { Total cholesterol / } \\
\text { HDL-cholesterol }\end{array}$ & $4.721 \pm 1.270$ & $5.686 \pm 1.699$ & 0.027 \\
\hline
\end{tabular}

" $\mathrm{P} \leq 0.05$ considered significant

\section{Discussion}

The rate at which breast cancer is spreading like an epidemic is alarming and there is a large number of cases reported in recent years [2]. This observation calls for urgent control and management of this type of cancer.

A decline in the cell-mediated immunity predisposes to oncogenesis [15], and a close association has been found between immune responses and macro- or micronutrient status [16]. 
This implies that it may be possible to monitor the prognosis of cancers using the levels of trace elements [1]. The present study is limited to just serum $\mathrm{Cu}, \mathrm{Zn}, \mathrm{Pb}$ and $\mathrm{Fe}$ trace elements, in addition to serum protein and cholesterol.

The findings shown in Table 1 indicate a strong association of $\mathrm{Cu}$ with breast cancer. Women with breast cancer exhibited a significant increase in the level of $\mathrm{Cu}(\mathrm{P}<0.009)$ as compared to the controls. The elevation of $\mathrm{Cu}$ level in breast carcinoma has been reported by numerous investigators $[1,3,4,17]$. It has been suggested that the copper ions and copper complexes react with hydrogen peroxide to form hydroxyl radicals that cause damage to protein, RNA and DNA. The damages are not repairable by cellular mechanisms thus initiating the malignant process [18]. In addition, angiogenesis (the growth of tumor blood supply) is essential for tumor growth, invasion and metastasis [19-21]. Molecular processes of angiogenesis that require copper as an essential cofactor for the stimulation of endothelial growth by tumor cytokine production (i.e., vasoendothelial growth factor), degradation of extracellular matrix proteins by metalloproteinases and migration of endothelial cells are mediated by integrins [22-24]. Consistently, high levels of copper have been found in many types of human cancers, including breast, prostate, colon and brain [25-27]. In human tumor-cell culture, it has been found that organic copper compounds inhibited the proteasome activity very rapidly $(15 \mathrm{~min})$ followed by induction of apoptosis [28]. So, we can say that although copper is an essential trace element for animals, its amount in an organism must be tightly regulated [29].

The serum-Zn level was significantly lower in the breast-cancer group $(\mathrm{p}<0.002)$ than in the control as shown in Table 1 . This finding agrees with that reported by some investigators [4, 17, 30,31] but not with others [1, 3, 32]. The exact role of $\mathrm{Zn}$ in carcinogenesis is unknown [4]. However, $\mathrm{Zn}$ is known to be essential for more than a hundred different metabolic functions [3, 33, 34]. It is required for DNA synthesis by altering the binding of $\mathrm{F}$ and $\mathrm{F}_{3}$ histones to DNA so as to affect RNA synthesis [35]. It is also essential for the activation of adenyl kinase, phosphodiesterase, membrane-bound adenyl cyclase and lipid peroxidase $[3,4]$. Experimentally, Zn deficiency and $\mathrm{Zn}$ supplementation have each shown both inhibition and stimulatory responses on tumor growth [3, 35], adding confusion to the role of $\mathrm{Zn}$ in human cancer.

The level of $\mathrm{Pb}$ was significantly elevated in the breast-cancer group $(\mathrm{p}<0.03)$ compared to the healthy group. During the past few decades, there has been growing recognition that metal compounds are an important class of environmental and occupational carcinogens [36, 37], and lead has been used to induce cancers in experimental animals [38]. Many of these studies have indicated that metal ions interact with nucleic 
acids to influence base-pairing and conformation. Such effects have been known to cause somatic mutation, a consequence of base-pairing errors of frame-shift mutations by deletion, leading to cellular transformation [39].

Table 1 shows that the level of Fe was insignificantly higher in the breast-cancer group. This finding agrees with that reported in previous studies [1, 3, 32]. This makes iron, as Becker et al [5] also suggest, a weak biomarker in the case of breast cancer.

The increased awareness of the role of trace elements and their interactions in metabolism and disease need a better understanding of the interrelationships of these metals for better understanding of their role in regulating tumor growth [3]. For trying to achieve this goal, we determined the $\mathrm{Cu} / \mathrm{Zn}$ ratio and the $\mathrm{Cu} / \mathrm{Fe}$ ratio. The latter ratio reflected insignificant change while the $\mathrm{Cu} / \mathrm{Zn}$ ratio exhibited a higher increase in the breast-cancer group. This finding is in agreement with that found by Lonesco and et al [37].

Table 2 shows that there were marked differences in the levels of total protein and total cholesterol (TC), and in the TC/HDL-C ratio for the healthy group and the breast-cancer group. The latter group exhibited a significantly higher level of total protein $(\mathrm{p}<0.005)$. Clinical hematological abnormalities have been reported in breast-cancer cases [40], which may lead to the elevation of proteins. This elevation agrees with that reported by Laursen et al [41], and it was stated that many globulin fractions were high in cancer cases [42]. Watabe [43] reported that the average level of $\alpha_{1}$-globulin in rat-serum during carcinogenesis was $2-4 \mathrm{mg} / \mathrm{dl}$ at the $6^{\text {th }}$ week, but after 13 weeks of carcinogenesis, it reached $60-100 \mathrm{mg} / \mathrm{dl}$.

Concerning serum TC, Table 2 shows that its level was significantly higher $(\mathrm{p}<0.001)$ in the breast-cancer group. This finding agrees with that reported by Hardwick et al [44] who state that cholesterol plays an important role in the mechanism underlying cell proliferation and cancer progression. It has been stated that high serum cholesterol, particularly in combination with properative weight, is a significant prognostic determinant of breast cancer [45].

Table 2 exhibits an insignificant increase in HDL-C, but Rossner and Wallgren [46] found that breast-cancer patients had a significantly higher level of serum cholesterol than the controls, $16 \%$ higher level in LDL-C and $13 \%$ higher level in HDL-C. On the other hand, it was stated that low HDL-C is associated with increased postmenopausal breast-cancer risk [47]. There are abundant data showing that animals fed fat diets rich in saturated, trans- or n6-fatty acids show a decrease in HDL-C and develop lifestyle-related cancers (breast, intestine, pancreas and colorectal) more readily than animals fed fat diets poor in these fatty acids [48]. The confusion in these results may be attributed to the wide age-range of the 
individuals used in the present study (including menarche and menapouse women), which has a relation to the level of TC, LDL-C and HDL-C [49]. To minimize the confusion, the ratio of TC/HDL-C was taken to consideration. The results shown in Table 2 exhibit a significant increase $(\mathrm{p}<0.005)$ in the amount of the ratio in the breast-cancer group compared to the control group, which reflects a positive correlation with breastcancer incidence.

In conclusion, the type and the level of some trace elements and the level of serum protein and cholesterol might have a correlation with breast cancer; the high level of $\mathrm{Cu}, \mathrm{Pb}, \mathrm{Cu} / \mathrm{Zn}$ ratio, total protein, total cholesterol and TC/HDL-C ratio, and the low level of $\mathrm{Zn}$ may be associated with an increased risk of breast cancer.

\section{Acknowledgments}

We would like to thank Muwaffaq Khalil Hasan, Department of Biology, College of Science, for his help in the analysis of the samples by atomic absorption spectrophotometer.

The cooperation of volunteers and the nursing staff of Al-Zahrawi Hospital is sincerely acknowledged.

\section{References}

1) Doll, R. and Peto, R, The causes of cancer: quantitative estimates of avoidable risks of cancer in the united state today. J. Nat1 Cancer Inst, 1988 66, 1191-1208.

2) Adebamowo, CA; Hu, FB; Cho, E; Spiegeiman, D; Holmes, MD and Willett, WC Dietary patterns and the risk of breast cancer. Ann. Epidemiol, 2005, 15(10); 789-795.

3) Arinola, OG and Charles-Davies, MA. Micronutrient levels in the plasma of Nigerian females with breast cancer. African J. Biotechnology, 2008, 7(11); 1620-1623.

4) Rizk, SL and sky-Peck, HH. Comparison between concentrations of trace elements in normal and neo-plastic human breast tissue. Cancer Research, 1984, 44; 5390-5394.

5) Becker, JS; Matusch, A; Dephoylu, C; Dobrowoiska J and Zoriy, MW. Quantitative imaging of selenium, copper and zinc in thin sections of biological tissues (slugs-genus Arion) measured by laser ablation inductively coupled plasma mass spectrometry. Anal. Chem. 2007, 79(16); 6074-6080.

6) Goyal, MM; Kalwar, AK; Vyas, RK and Bhati, A. A study of serum zinc, selenium and copper levels in carcinoma of esophagus patients. Indian J Clinic. Biochem. 2006, 21(1); 208-210.

7) Cui, Y.; Vogt, S.; Olson, N.; Glass, A.G. and Roban, T.E.. Levels of zinc, selenium, calcium and iron in benign breast tissue and risk of 
subsequent breast cancer. Cancer Epidemiology Biomarkers and Prevention, 2007, 16(1), 1682-1689.

8) Rossner, S. and Wallgren, A.Serum lipoproteins and proteins after breast cancer surgery and effects of tamoxifen. Atherosclerosis, 1984, 52(3), 339-346.

9) Hardwich, M; Fertikh, D.; Culty, M.; Li, M; Vidic, B and Papadopoulos, V. Periveral-type benzodiazepine receptor (PBR) in human breast cancer. Cancer Research, 1999, 59; 831-840.

10) Paul, I; Tartter; MD; Angelos, E; Papatestas, MD; John-Joannovich, MD and Michael, N. Cholesterol and obesity as prognostic factors in breast cancer. Cancer, 1981, 47(9); 2222-2227.

11) Christenson, R.H.; Gregory, L.C. and Johnson, L.J. Appleton and Lange's Outline Review Clinical Chemistry. Appelton and Longue Review/McGraw-Hill medical publishing division, New York, 2001.

12) Oguntibeju, $O$ and Fafunso $M$. Relationship between serum ascorbate, cholesterol and total protein levels in patient with NIDDM. J. Med. Sci., 2002, 2(5); 230-233.

13) Mende, CW. Improving antihypertensive therapy in patients with diabetic nephropathy. Southern Med. J, 2006, 99(2); 150-155.

14) Willard, H.H; Meritt, L.L. and Dean, J.A. "Instrumental Methods of Analysis", $5^{\text {th }}$ ed. D. Van Nostrand Company, New York, 1974.

15) Gowal, S; de Giacoms, $M$ and Le Boudec, JY. A validated mathematical method of cell-mediated immune response to tumor growth. Cancer Res., 2007, 67(17), 8419-21.

16) Wintergerst, ES; Maggini, $S$ and Horning DH. Contribution of selected vitamins and trace elements to immune function. Ann. Nutr. Metab., 2007, 51(4), 301-323.

17) Sanjeev, K.; Gupta, MS; Vijay, K; Shukla, MCH and others. Serum trace elements and $\mathrm{Cu} / \mathrm{Zn}$ ratio in breast cancer patients. J. Surgical Oncology, 2006, 46(3), 178-181.

18) Filomeni, G; Cerchiaro, G; Da Costa Ferreira AM; De Martino, A; Pedersen, JZ; Ratilio, G; and Ciriolo, MR. Pro-apoptotic activity of novel isatin. Schiff base copper $_{\text {II }}$ complexes depends on oxidative stress induction and organelle-selective damage. J. Biol. Chem., 2007, 282(16): 12010-21.

19) Eatock, MM; Schatziein, A and Kaye, SB. Tumor vasculature as a target for anticancer therapy. Cancer Treat. Rev., 2000, 26; 191-204.

20) Dutcher, JP. Angiogensis and melanoma. Curr. Oncol. Rep., 2001, 3; 353-58.

21) Skibniewska, E; Kos'la and Skibniewski, M. Copper content in neoplastic and healthy mammary glands in dogs. Bull. Vet. Inst. Pulawey, 2010, 54, 269-72. 
22) Brewer, GJ. Copper control as an antiangiogenic anticancer therapy; lessons from treating Wilson's disease. Exp. Biol. Med., 2001, 226: 665-73.

23) Brem, S. Angiogenesis and cancer control; From concept to therapeutic trial. Cancer Control, 1999, 6: 436-58.

24) Theophanides $T$ and Anastassopoulow J. Copper and carcinogenesis. Crit. Rev. Oncol. Hematol. 2002, 42: 57-64.

25) Kuo, HW; Chen, SF; Wu, CC; Chen, DR and Lee JH. Serum and tissue trace elements in patients with breast cancer in Taiwan. Biol. Trace Elem Res. 2002, 89: 1-11.

26) Sharma, K; Mittal, DK; Kesarwani, RC and Kamboj, VP. Diagnostic and prognostic significance of serum tissue trace elements in breast malignancy. Indian J. Med. Sci., 1994, 48: 227-32.

27) Margalioth, EJ; Schenker, JG and Chevion M. Copper and zinc levels in normal and malignant tissues. Cancer, 1993, 52: 868-72.

28) Daniel, KG; Gupta, P; Harbach, RH; Guida, WC and Dou, QP. Organic copper complexes as a new class of proteasome inhibitors and apoptosis inducers in human cancer cells. Biochem. Pharmacol. 2004, 67: 1139-51.

29) Navarro, SSA and Rohan, TE. Trace elements and cancer risk: a review of the epidemiologic evidence. Cancer Causes Contr., 2007, 18(1): 7-27.

30) Kuo, HW; Chen, SF; Wu, CC and Lee, JH. Serum and tissue trace elements in patients with breast cancer in Taiwan. Biol. Trace Elem. Res., 2002, 89(1): 1-11.

31) Yücel, I; Arpaci, F; Ozet, A; Döner, B; Karayilanoġlu, T; Sayar, A and Berk, O. Serum copper and zinc levels and copper/zinc ratio in patients with breast cancer. Biol. Trace Elem. Res. 1994, 40(1):31-8.

32) Huang, YL; Sheu, JY and Lin, TH. Association between oxidative stress and changes of trace elements in patients with breast cancer. Clin. Biochem., 1999, 32(2): 130-6.

33) Martin-Moreno, JM; Gorgio, L; Riemersma, RA; Gomez-Aracena, J and Kark, JD. Myocardial infarction risk in relation to zinc concentration in toenails. British J. Nutri., 2003, 89: 673-8.

34) Oteiza, PI and Mackenzie, GG. Zinc, oxidant-triggered cell signaling, and human health. Molec. Aspe. Medic., 2005, 26:245-55.

35) Prasad, AS. Discovery of human $\mathrm{Zn}$ deficiency and studies in an experimental human model. Am. J. Clinic. Nutr., 1991, 53: 403-12.

36) Diez, M; Arroyo, M; Cerdan, FJ; Munoz, M; Martin, MA and Balibrea, JL. Serum and tissue trace metal levels in lung cancer. Oncology, 1989, 436: 230-4.

37) Lonescu, JG; Novotny, J; Stejskal, V; Lätsch A; Blaurock-Busch, E and Eisenmann-Klein, M. Increased level of transition metals in 
breast cancer tissue. Neuroendo-crinology letters, 2006, 27(1): 36-9.

38) Sunderman, FW. Carcinogenic effects of metal. Fed. Proc., 1978, 37:40-8.

39) Welnstein, IB. Current concepts in mechanisims of clinical carcinogenesis. Bull. NY. Acad. Med., 1978, 54: 366-83.

40) Boehm, DU; Lebrecht, A; Schmidt, M; Siggelkow, W; Linder, C; Litz, A; Ulbrich, E and Koelbl, H. Prognostic impact of haemoglobin levels in breast cancer. Anticancer Res., 2007, 27(2): 1223-36.

41) Laursen, I; Briand, $P$ and Lykkesfeldt, AE. Serum albumin as a modulator on growth of the human breast cancer cell line. Anticancer Res., 1990, 10(2): 343-51.

42) Christenson, RH; Gregory, LC and Johnson, LJ. Appleton and Lange's Outline Review Clinical Chemistry. McGraw-Hill, Medical Publishing Division, New York, USA, 2001: p.58.

43) Watabe, H. Early appearance of embryonic $\alpha$-globulin in rat serum during carcinogenesis with 4-Dimethyl amino azo benzene. Cancer Res., 1971, 31: 119-29.

44) Hardwick, M; Fertikh, D; Culty, M; Li, H; Vidic, $B$ and Papadopoulos, V. Peripheral-type benzodiazepine receptor (PBR) in human breast cancer. Cancer Res., 1999, 59: 831-39.

45) Paul, I; Tartter, MD; Angelos, E; Papatestas, MD; John-Ioannovich, MD and Michael, N. Cholesterol and obesity as prognostic factors in breast cancer. Cancer, 1981, 47(9): 2222-27.

46) Rossner, $S$ and Wallgren, A. Serum lipoproteins and proteins after breast cancer surgery and effects of tamoxifen. Atherosclerosis, 1984, 52(3): 339-49.

47) Furberg, AS; Vcierod, MB; Wilsgard, T; Bernstein, L and Thune, I. Low HDL-cholesterol is associated with increased post-menopausal breast cancer risk. J. Nat. Cancer Inst., 2004, 96(15): 1152-60.

48) FAO/WHO. "Fats and Oils in Human Nutrition Report of Joint Expert Consultation". FAO, Rome; FAO Food and Nutrition, 1994, 57.

49) Espeland, MA; Marcovina, SM; Miller, V; Wood, PD; Wasilauskas, $\mathrm{C}$ and Sherwin, R. Effect of postmenopausal hormone therapy on lipoprotein concentration. Criculation, 1998, 97: 979-86. 